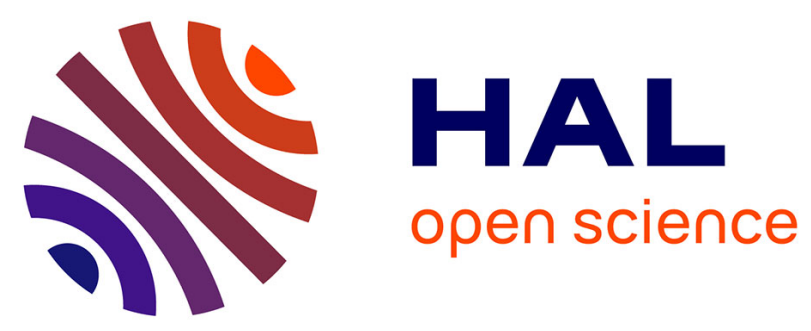

\title{
INTERNAL FRICTION AND ULTRASONIC ATTENUATION ASSOCIATED WITH THE NORMAL TO INCOMMENSURATE TRANSITION IN NiTi(Fe) ALLOY
}

Guei Jian-Ming, Zhu Jin-Song, Wang Ye-Ning

\section{To cite this version:}

Guei Jian-Ming, Zhu Jin-Song, Wang Ye-Ning. INTERNAL FRICTION AND ULTRASONIC ATTENUATION ASSOCIATED WITH THE NORMAL TO INCOMMENSURATE TRANSITION IN NiTi(Fe) ALLOY. Journal de Physique Colloques, 1985, 46 (C10), pp.C10-641-C10-644. 10.1051/jphyscol:198510141 . jpa-00225347

\section{HAL Id: jpa-00225347 https://hal.science/jpa-00225347}

Submitted on 1 Jan 1985

HAL is a multi-disciplinary open access archive for the deposit and dissemination of scientific research documents, whether they are published or not. The documents may come from teaching and research institutions in France or abroad, or from public or private research centers.
L'archive ouverte pluridisciplinaire HAL, est destinée au dépôt et à la diffusion de documents scientifiques de niveau recherche, publiés ou non, émanant des établissements d'enseignement et de recherche français ou étrangers, des laboratoires publics ou privés. 
JOURNAL DE PHYSIQUE

Colloque C10, supplément au $\mathrm{n}^{\circ} 12$, Tome 46, décembre 1985 page Cl0-64l

\title{
INTERNAL FRICTION AND ULTRASONIC ATTENUATION ASSOCIATED WITH THE NORMAL TO INCOMMENSURATE TRANSITION IN NiTi(Fe) ALLOY
}

\author{
GUEI JIAN-MING, ZHU JIN-SONG AND WANG YE-NING \\ Institute of Solid state Physics and Department of Physics, \\ Nanjing University, China
}

\begin{abstract}
Two ultrasonic attenuation maxima with two corresponding minima of longitudinal sound velocity and two internal friction peaks have been measured in $\mathrm{NiTi}(\mathrm{Fe})$ alloy on cooling at about $-26^{\circ} \mathrm{C}$ and $-90^{\circ} \mathrm{C}$ respectively. EM observation shows the maximum at $-26^{\circ} \mathrm{C}$ is associated with the normal-incormensurate transition whereas that at $-90^{\circ} \mathrm{C}$ is due to lock-in transition. The mechanism of the internal friction associated with N/I transition is centered on.
\end{abstract}

\section{I - INTRODUCTION}

A number of anomalies have been observed in NiTi alloys above the martensitic transition temperature, which was considered to be the pre-martensitic effect. Electron microscopic investigation made by wayman /1/ on $\mathrm{NiTi(Fe)} \mathrm{alloys} \mathrm{shows} \mathrm{that} \mathrm{these}$ anomalies are induced by the normal-incormensurate(N/I) transition and the subsequent incommensurate-commensurate (I/C) or named lock-in transition which has no direct relationship with martensitic transition. Discomtnensurations have been found in NiTi by Michal $/ 2 /$ through lattice images. The incommensurate phase transition has been observed in many crystals in recent years. However, ultrasonic attenuation and sound velocity studies related to the $\mathrm{N} / \mathrm{I}$ and I/C transition were made in only a few crystals such as $\mathrm{Rb} 2 \mathrm{ZnCl}_{4}, \mathrm{~K}_{2} \mathrm{ZnCl}_{4} / 3 /$ and $\mathrm{K}_{2} \mathrm{SeO}_{4} / 4 /$ and internal friction measurements were made in NiTi (Fê) $/ 5 /, \mathrm{TaSe}_{2} / 6 /$ at $\mathrm{KHz}$ range. Analysis was made on the variation of $\mathrm{C}_{55}$ in the vicinity of $\mathrm{I} / \mathrm{C}$ transition in $\mathrm{K}_{2} \mathrm{SeO}_{4}$, considering the influence of discommensurations, but no satisfactory theoretical explanation has been made for internal friction and attenuation coefficient associated with $\mathrm{N} / \mathrm{I}$ transition yet. In this paper, $\mathrm{NiTi}(\mathrm{Fe})$ is used because in this alloy, the $\mathrm{C} / \mathrm{I}$ transition temperature $\left(T_{C}\right)$ is widely separated from the $\mathrm{N} / \mathrm{I}$ transïtion temperature $\left(\mathrm{T}_{\dot{j}}\right)$ that enables one to concentrate on the ultrasonic attenuation and internal friction investigations of N/I transition. Some electron microscopic observations have been made and the mechanism of internal friction are discussed. 
II - EXPERIMENTAL TECHNIQUE

The samples with concentration 52.12 at: $\mathrm{Ti}, 46.06$ at: $\mathrm{Ni}$ and 1.82 at\% $\mathrm{Fe}$, were treated with standard method $/ 1 \%$. Internal friction $\left(Q^{-1}\right)$ was measured by an inverted torsion pendulum and ultrasonic attenuation by Matec Model 6600 and sound velocity measurement was carried out using pulse echo overlap method on the same apparatus.

\section{III - EXPERIMENTAL RESULTS AND DISCUSSION}

\section{(1) ultrasonic attenuation and sound velocity}

ultrasonic attenuation measured on cooling shows that there are two attenuation maxima at $-26^{\circ} \mathrm{C}$ and $-90^{\circ} \mathrm{C}$ respectively with two correspending minima of longitudinal sound velocity (Fig. 1). Electron microscopic observation shows that weak superlattice diffraction spots near $1 / 3(110)$ and $1 / 3$ (111) position of $B_{2}$ structure appear at

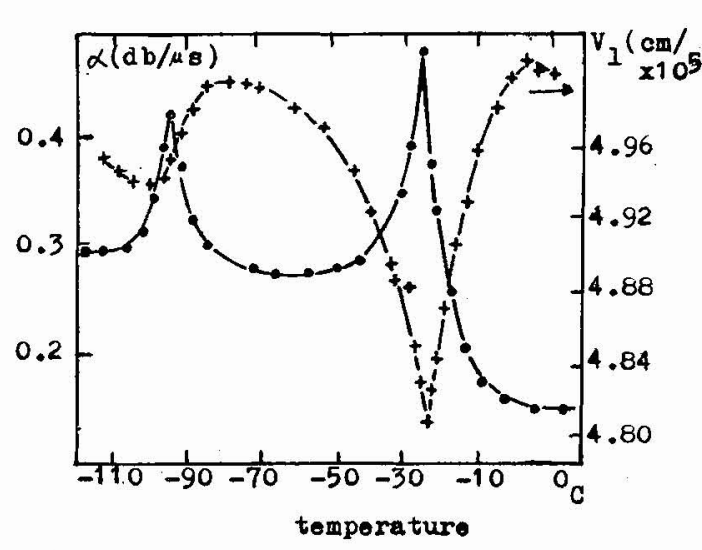
about $-26^{\circ} \mathrm{C}$ and intensify with de-

) creasing temperature(Fig. 2) until forming needle-like domains of $R$ phase about $-90^{\circ} \mathrm{C}$ (Fig. 3), which is in accordance with Wayman's EM observation on the analogous alloy $/ 1 /$. It is convincible that $-26^{\circ} \mathrm{C}$ attenuation maximum is related to the $\mathrm{N} /$ I transition whereas the maximm at $-90^{\circ} \mathrm{C}$ is due to I/C transition. Since the phase formed in the I/C transition bears the characteristics of martensite, it is reasonable to consider the mechanism of attenuation to be similar to that of MT $/ 7 / 8 /$. Fig. 4 shows the attenuation measured at 4.6-12.1 MHz in the process of N/I transition, it is clearly seen that the atten-

Fig. 1 - Attenuation and longitudinal sound velocity as function of temperature at $4.6 \mathrm{MHz}$

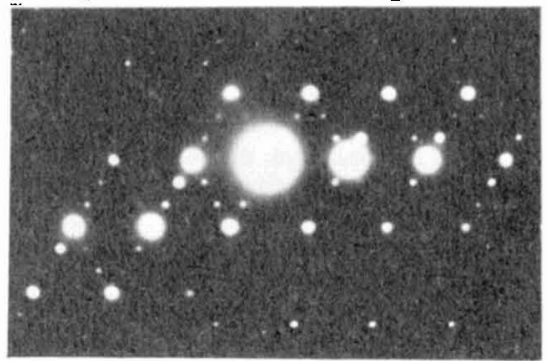
uation is proportional to the square of measuring frequency (Fig. $4(\mathrm{~b})$ )

Fig. 2 - $\left[^{[111]_{B 2}}\right.$ zone diffraction patterns showing $1 / 3$ (110) superlattice reflections at $-40^{\circ} \mathrm{C}$

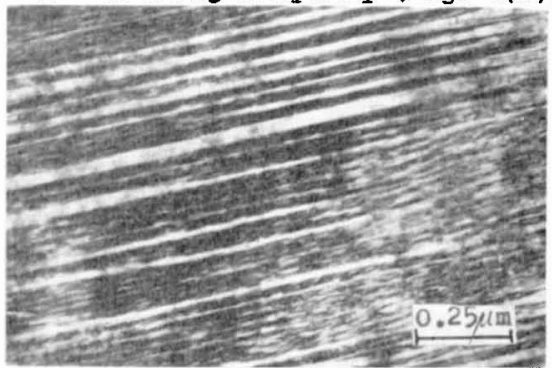

Fig. 3 - Eletron micrograph showing a typical example of needle domains at $-95^{\circ} \mathrm{C}$

in which the background attenuation in higher temperature side has been deducted However, the variation of sound velocity shows no dispersion in the frequency range. Though the square relation is obeyed both in fluctuation dissipation mechanism and phonon relaxation, we consider, in view of the linkage between N/I transition and the softening of acoustic phonon, that bilinear interaction of ultrasonic wave with soft 


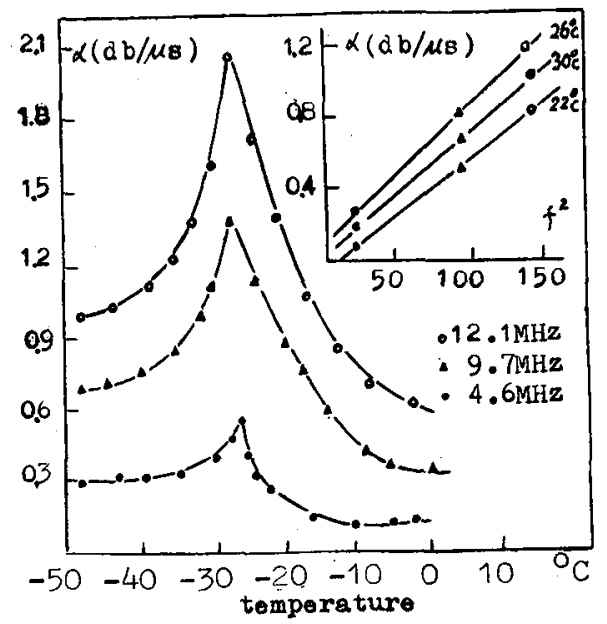

Fig. 4 - (a) Attenuation as function of temperature at $4.6 \mathrm{MHz}, 9.7 \mathrm{MHz}$, 12. I MHz (b) Attenuation vs square of measuring frequency at different temperature.

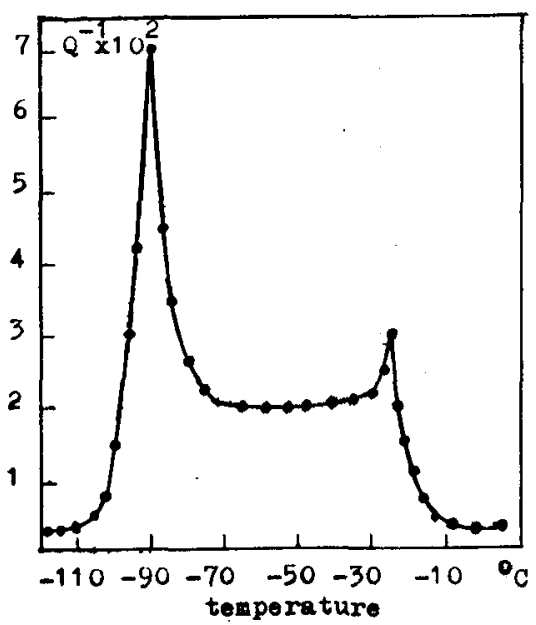

Fig. 5 - Internal friction as function of temperature at $\mathrm{f}=1.7 \mathrm{~Hz}$ and $\mathrm{T}=1^{\circ} \mathrm{C} / \mathrm{min}$. phonon to be the principal cause of the attenuation.

\section{(2) Internal Friction}

The $\mathrm{Q}^{-1}$, measured in an inverted torsion pendulum on cooling (fig. 5), shows a small peak about $-26^{\circ} \mathrm{C}$ and a larger one about $-90^{\circ} \mathrm{C}$ with a high plateau between two peaks. EM analysis manifests that peak at $-26^{\circ} \mathrm{C}$ is associated with $\mathrm{N} / \mathrm{I}$ transition while the one at $-90^{\circ} \mathrm{C}$ with $\mathrm{I} / \mathrm{C}$ transition. Thinking on the presence of needle type domains in the lock-in transition similar to the situation in martensitic transition, it is reasonable to attribute internal friction to stress induced motion of interphase boundaries of $\mathrm{R}$ phase $/ 9 /$. The $\mathrm{Q}^{-1}$ in $\mathrm{N} / \mathrm{I}$ transition at different frequencies and heating rate was measured (fig. $6(\mathrm{a})$ ) and the linearity of $Q_{\mathrm{m}}^{-1}$ to $\dot{T} / f$ is obtained (Fig. 6(b)). The none-zero intercept of the longitudinal axis implies the $\mathrm{Q}^{-1}$ under isothermal condition. Magnitude of

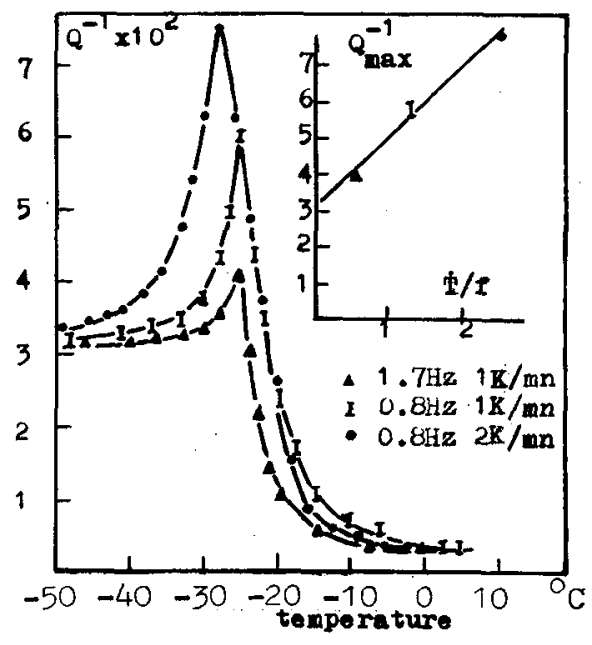

Fig. 6 - (a) Internal friction as function of temperature at different measuring frequency and heating rate.

(b) $Q_{\max }^{-1}$ vs $\mathrm{T} / \mathrm{f}$

$\mathrm{Q}^{-1}$ at $\dot{\mathrm{T}}=\mathrm{O}$ is approximately equal to plateau between the two peaks which does not change, with $\dot{T}$ and $f$. Actually phonon relaxation does not contribute to $Q^{-1}$ at $f=1 \mathrm{~Hz}$. The $Q$ proportional to $T / f$ being common to first order phase transition. the mechanism of $Q^{-1}$ is considered to be similar to that of martensitic transformation suggested by one of the authors $/ 10 /$. When an object under constant surface traction is subjected to change of elastic stiffness due to phase transition, the elastic energy will also changes, half of the work done by applied stress is turn into elastic energy, and the other half dissipated /11/. Since the measurement of sound velocity shows a steep change in the vicinity of $\mathrm{T}_{i}$ and applied stress can be treated as 
constant in the instance of change, half of work done by applied stress is dissipated which give rise to internal friction. The larger the change of elastic constant in a vibration period, the larger the internal friction, namely $Q^{-1} \propto \dot{T} / f$. Because the height of the $Q^{-1}$ plateau at the lower temperature side of the $\mathrm{I} / \mathrm{C}$ transition peak does not change either with $\dot{T}$ or $f$, we consider it to be the static hysteresis loss due to the existance of discommensuration in this temperature range. In the $\mathrm{NiTi}(\mathrm{Fe}) / 1 /$ alloy, the lattice and incommensurate modulation lock-in and become commensurate principally through the rhombohedral distortion due to the abrupt expansion along \&111> direction about $\mathrm{T}_{\mathrm{C}}$ and the number of discommensurations almost remain unchanged in the incommensurate phase. So a stable $Q^{-1}$ plateau appears. We intend to observe the relation between $Q^{-1}$ and the lattice inages of discommensuration by means of high resolution electron microscopy. Mercier's /3/ investigation of $Q^{-1}$ in NiTi (Fe) with similar content at $\mathrm{KHz}$ range shows no obvious peak at $\mathrm{T}_{i}$ and a broad protrusion in the region of N/I transition, it may be attributed to the increase of frequency much more than $\mathrm{IHz}$ so that make $\mathrm{T}_{\mathrm{f}}$ tend to zero. It is also easy to explain that why the $Q^{-1}$ peak of $\mathrm{N} / \mathrm{I}$ transition measured at $3.69 \mathrm{KHz}$ is much lower than that obtained at $0.5 \mathrm{KHz}$ in $\mathrm{TaSe}_{2} / 6 /$.

\section{REFERENCES}

/1/ Hwang, C. M., Meichle, M., Salamon, M. B. and Wayman, C. M., Philo. Mag. 47 (1983) 9.

/2/ Michal, C. M., et. al, Acta Metal. 30 (1982) 125.

13/ Shunsube Hirotsu, Kiyoshi toyta and katsumi Hamano, Ferroelectrics 36 (1981)319.

14/ Rehwald,W. and Vonlanthen,A. Solid state Commun. 38 (1981) 209.

15/ Mercier, O., Tirbonod B. and Torok, E., J.de physique C5 (1981) 1073.

16/ Barmatz, M., Testardi L. R. and Di Salvo, F. J., Phys. Rev. B12 (1975) 4367.

17/ Zhu Jin-song, Wang Ye-ning and Shen Hui-min, J. de Physique C9 (1983) 235.

/8/ Pace, N. G. and Saunders, G. A. Philo. Mag. 22 (1970) 73

19/ wang Ye-ning, et al, Proc. First China-U. S. A. Bilateral metallurgical conference (1981) 552 Beijing. Wang Ye-ning,et al, J. de physique C5 (1981) 1049.

/10/ wang Ye-ning, et al, Scient is Sinica IX (1960) 197.

/11/ Eshelby, J.D.(1956) Solid State Physics 3,79-100. 